\title{
Effect of Nitrogen and Phosphorus Fertilizers on Growth and Yield of Quality Protein Maize (QPM)
}

\author{
Nandita Jena ${ }^{1}$, K.P. Vani ${ }^{2}$, V. Praveen Rao ${ }^{3}$, A. Siva Sankar ${ }^{4}$ \\ College of Agriculture, ANGRAU, Rajendranagar
}

\begin{abstract}
Response of quality protein maize hybrid (HQPM-1) to various $N$ and P levels was studied at College Farm, College of Agriculture, Rajendranagar, Hyderabad during kharif 2012. Quality protein maize was tested with four nitrogen levels $(0,120,180$ and

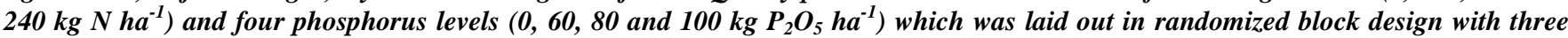
replications at a spacing of $60 \times 20 \mathrm{~cm}$. Results showed that each incremental effect of nitrogen and phosphorus fertilizers significantly increased the plant height, LAI, dry matter production and yield (grain and stover) of HQPM-1 hybrid over control. Application of $240 \mathrm{~kg} \mathrm{~N} \mathrm{ha}^{-1}$ gave maximum plant height (212.75 cm), LAI (3.89), dry matter production $\left(13432 \mathrm{~kg} \mathrm{ha}^{-1}\right)$, grain yield $\left(6383 \mathrm{~kg} \mathrm{ha}^{-1}\right)$ and stover yield $\left(7050 \mathrm{~kg} \mathrm{ha}^{-1}\right)$ followed by $180,120 \mathrm{~kg} \mathrm{~N} \mathrm{ha}^{-1}$ and control. Similarly, $100 \mathrm{~kg} \mathrm{P}_{2} \mathrm{O}_{5} \mathrm{ha}^{-1}$ resulted in highest plant height (185.95 $\mathrm{cm})$, LAI (3.17), dry matter production (10572 $\left.\mathrm{kg} \mathrm{ha}^{-1}\right)$, grain yield $\left(5010 \mathrm{~kg} \mathrm{ha}^{-1}\right)$ and stover yield (5562 $\left.\mathrm{kg} \mathrm{ha}^{-1}\right)$. It is concluded that N and $P$ should be applied at the rate of $240 \mathrm{~kg} \mathrm{ha}^{-1}$ and $100 \mathrm{~kg} \mathrm{ha}^{-1}$ for quality protein maize to realize good yields in the agro-ecological conditions of South Telangana region of A.P.
\end{abstract}

Keywords: Quality protein maize, Nitrogen and Phosphorus fertilizers, growth parameters, Yield

\section{Introduction}

Maize (Zea mays) the American Indian word for corn means literally "that which sustains life". Maize is emerging as an important world cereal crop after wheat and rice, which is considered as "Queen of Cereals", due to the high productiveness, easy to process, low cost than other cereals [Jaliya et al., 2008], provides nutrients for humans and animals, serves as basic raw materials for production of starch, oil, alcoholic beverages, and more recently fuel [Punita, 2006]. It is a good source of carbohydrates, fat, protein and some important vitamins and minerals, but deficient in essential amino acids viz., lysine and tryptophan that reduces its biological value. The amount of these deficient amino acids has been increased by incorporating opaqe-2 gene in quality protein maize (QPM) [Bisht $e t$ al. 2012]. Hence, the cultivation of QPM provides an opportunity to the farmers to produce nutritionally superior maize grains, where maize is a staple food and potential source of proteins in many developing countries of Latin America, Africa and Asia. At global level maize accounts for $15 \%$ proteins and $20 \%$ of calories in world food diet [Prasanna et al., 2001]. The potentiality of maize manifested in the form of growth, grain yield and yield attributes is remarkably affected by various biotic and abiotic factors, of which nutrient management is prime one. Undoubtly, being heavy feeder of nutrients and high productivity potential, maize crop requires continuous and assured nutrient supply throughout the growing period from germination to grain filling stage. Thus proper nutrient management with Nitrogen and Phosphorus fertilizers for QPM hybrid is important to realize higher yields.
Nitrogen is a component of protein, nucleic acids and other compounds essential for plant growth process [Onasanya et al., 2009]. It is a major plant growth and yield determining nutrient required for maize production [Manzoor et al., 1999]. Generally, phosphorus is the second crop limiting nutrient in most of the soils. Phosphorus is needed for growth, utilization of sugar and starch, photosynthesis, metabolic process which leads to higher yield potential [Ayub et al., 2002]. Hence considering nutritive values and productivity of QPM, the present experiment on nutrient management on QPM was initiated.

\section{Materials and Methods}

A field experiment was conducted on Quality Protein Maize during kharif 2012, at College Farm, College of Agriculture, Rajendranagar, Hyderabad. The experiment consisted of four levels $\mathrm{N}\left(0,120,180\right.$ and $\left.240 \mathrm{~kg} \mathrm{ha}^{-1}\right)$ and $\mathrm{P}$ $\left(0,60,80\right.$ and $\left.100 \mathrm{~kg} \mathrm{ha}^{-1}\right)$ with three replications in Randomized Block Design. The soil was classified as sandy loam, neutral in soil reaction $\left(\mathrm{p}^{\mathrm{H}}-6\right)$, rich in organic carbon $(0.43 \%)$, medium in available nitrogen (309 $\left.\mathrm{kg} \mathrm{ha}^{-1}\right)$, phosphorus $\left(31.23 \mathrm{~kg} \mathrm{ha}^{-1}\right)$ and available potassium $(320 \mathrm{~kg}$ $\left.\mathrm{ha}^{-1}\right)$. The annual rainfall of the region is $532.8 \mathrm{~mm}$. Quality Protein Maize hybrid (HQPM-1) was sown $9^{\text {th }}$ July 2012 with a seed rate of $20 \mathrm{~kg} \mathrm{ha}^{-1}$ at a spacing of $60 \times 20 \mathrm{~cm}$. A uniform basal dose of potassium $\left(80 \mathrm{~kg} \mathrm{ha}^{-1}\right)$ and graded levels of phosphorus was applied basally at sowing. Nitrogen in the form of urea as per levels was applied as basal (sowing time) and in splits (30 DAS, 45 DAS). Crop was harvested on Oct $18^{\text {th }} 2012$. 


\section{International Journal of Science and Research (IJSR) \\ ISSN (Online): 2319-7064}

Index Copernicus Value (2013): 6.14 | Impact Factor (2014): 5.611

Table 1: Effect of nitrogen and phosphorus fertilizer on growth and yield of quality protein maize

\begin{tabular}{|c|c|c|c|c|c|}
\hline Treatment & Plant height $(\mathrm{cm})$ & LAI & $\begin{array}{c}\text { Dry matter production } \\
\left(\mathrm{kg} \mathrm{ha}^{-1}\right)\end{array}$ & $\begin{array}{c}\text { Grain yield } \\
\left(\mathrm{kg} \mathrm{ha}^{-1}\right)\end{array}$ & $\begin{array}{c}\text { Stover yield } \\
\left(\mathrm{kg} \mathrm{ha}^{-1}\right)\end{array}$ \\
\hline \multicolumn{6}{|c|}{ Nitrogen Levels $\left(\mathrm{kg} \mathrm{ha}^{-1}\right)$} \\
\hline 0 & 116.04 & 1.33 & 4022 & 1823 & 2198 \\
\hline 120 & 181.12 & 2.39 & 9176 & 4256 & 4920 \\
\hline 180 & 202.94 & 3.59 & 11832 & 5585 & 6247 \\
\hline 240 & 212.75 & 3.89 & 13432 & 6383 & 7050 \\
\hline $\mathrm{SE} \mathrm{m} \pm$ & 1.65 & 0.05 & 198 & 93 & 105 \\
\hline $\mathrm{CD}(\mathrm{P}=0.5)$ & 4.78 & 0.15 & 573 & 269 & 304 \\
\hline \multicolumn{6}{|c|}{ Phosphorus Levels $\left(\mathrm{kg} \mathrm{ha}^{-1}\right)$} \\
\hline 0 & 170.55 & 2.35 & 8176 & 3798 & 4378 \\
\hline 60 & 175.43 & 2.74 & 9616 & 4490 & 5126 \\
\hline 80 & 180.90 & 2.94 & 10098 & 4749 & 5348 \\
\hline 100 & 185.95 & 3.17 & 10572 & 5010 & 5562 \\
\hline $\mathrm{SE} \mathrm{m} \pm$ & 1.65 & 0.05 & 198 & 93 & 105 \\
\hline $\mathrm{CD}(\mathrm{P}=0.5)$ & 4.78 & 0.15 & 573 & 269 & 304 \\
\hline \multicolumn{6}{|c|}{ Interaction $(\mathrm{N} \times \mathrm{P})$} \\
\hline $\mathrm{SE} \mathrm{m} \pm$ & 3.31 & 0.10 & 396 & 186 & 211 \\
\hline $\mathrm{CD}(\mathrm{P}=0.5)$ & NS & NS & NS & NS & NS \\
\hline
\end{tabular}

\section{Results and Discussion}

The growth parameters like plant height, leaf area index and dry matter production was significantly affected by the application of nitrogen and phosphorus at different levels [Table.1]. Maize crop fertilized with $240 \mathrm{~kg} \mathrm{~N} \mathrm{ha}^{-1}$ had significantly resulted in long statured plants $(212.75 \mathrm{~cm})$, higher leaf area index (3.89) and dry matter production at harvest (13432 $\left.\mathrm{kg} \mathrm{ha}^{-1}\right)$, compared to other nitrogen levels $\left(180,120 \mathrm{~kg} \mathrm{~N} \mathrm{ha}^{-1}\right.$ and control). Application of phosphorus with $100 \mathrm{~kg} \mathrm{P}_{2} \mathrm{O}_{5}$ ha $^{-1}$ produced significantly the taller plants $(185.95 \mathrm{~cm})$, maximum LAI $(3.17)$, dry matter production $\left(10572 \mathrm{~kg} \mathrm{ha}^{-1}\right)$ while these growth parameters was minimum in unfertilized plots and significantly higher than other , $\mathrm{p}^{\text {ec }}$ levels $\left(60,80 \mathrm{~kg} \mathrm{P}_{2} \mathrm{O}_{5} \mathrm{ha}^{-1}\right)$. The nitrogen has beneficial effect on plant metabolism which affect physiological process of the crop and thereby increases the growth parameters [Jeet et al., 2012]. Likewise effect of high phosphorus levels on growth parameters were probably due to better development of root system and nutrient absorption [Masood et al., 2011].

Among the four levels of nitrogen and phosphorus tested on maize, higher dose of nitrogen i.e. $240 \mathrm{~kg} \mathrm{~N} \mathrm{ha}^{-1}$ produced significantly maximum grain yield $\left(6383 \mathrm{~kg} \mathrm{ha}^{-1}\right)$ and stover yield $\left(7050 \mathrm{~kg} \mathrm{ha}^{-1}\right)$ followed by $180,120 \mathrm{~kg} \mathrm{~N} \mathrm{ha}^{-1}$ and control. Likewise the phosphorus @ $100 \mathrm{~kg} \mathrm{ha}^{-1}$ resulted in significantly superior grain yield $\left(5010 \mathrm{~kg} \mathrm{~h}^{-1}\right)$ and stover yield $\left(5562 \mathrm{~kg} \mathrm{ha}^{-1}\right)$ over $80,60 \mathrm{~kg} \mathrm{P}_{2} \mathrm{O}_{5} \mathrm{ha}^{-1}$ and unfertilized maize. This significant increase in yield parameters was due to application of higher doses of $\mathrm{N}$ and $\mathrm{P}$ fertilizers which enhanced nutrients uptake by the crop, by better translocation of photosynthates from source to sink. Grain and stover yield is also higher due to higher growth and yield parameters like plant height, LAI, dry matter production, cob length and girth, number of grains $\mathrm{cob}^{-1}$, test weight etc. These results are in accordance with those obtained by Singh and Nepalia et al., 2009.

\section{References}

[1] M. Ayub, M.A. Nadeem, M.S. Sharar and N. Mahmood. Response of maize (Zea mays L.) fodder to different levels of nitrogen and phosphorus. Asian Journal of Plant Science. (1), pp. 352-354. 2002.

[2] M.M. Jaliya, A.M. Falaki, M. Mahmud, I.U. Abubakar, and Y.A. Sani. Response of Quality Protein Maize (QPM) (Zea Mays L.) to sowing date and NPK fertilizer rate on yield \& yield components of Quality Protein Maize. Savannah Journal of Agriculture. (3), pp. 24-35. 2008.

[3] S. Jeet, J.P. Singh, R. Kumar, R.K. Prasad, P. Kumar, A. Kumari, and P. Prakash. Effect of nitrogen and sulphur levels on yield, economics and quality of QPM hybrids under dryland condition of eastern uttar pradesh, India. Journal of Agricultural Sciences. 4 (9), pp. 31-38. 2012.

[4] Z. Manzoor, T.H. Awan, M.E. Safdar, R.I. Ali, M.M. Ashraf and M. Ahmad. Effect of nitrogen levels on yield and yield components of Basmati 2000. Journal of Agricultural Research. 44(2), pp. 115-120. 2010.

[5] T. Masood, R. Gul, F. Munsif, F. Jalal, Z. Hussain, N. Noreen, H. Khan, Nasiruddin and H. Khan. Effect of different phosphorus levels on the yield components of Maize. Sarhad Journal of Agriculture. 27(2), pp. 167170. 2011

[6] R.O. Onasanya, O.P. Aiyelari, A. Onasanya, S. Oikeh, F.E.N. Nwilene, and O.O. Oyelakin. Growth and yield response of maize to different rates of nitrogen and phosphorus fertilizers in southern Nigeria. World Journal of Agricultural Sciences. 5(4), pp. 400-407. 2009.

[7] G. Punita, Physico chemical properties, Nutritional quality \& Value addition to Quality Protein Maize. M.Sc Thesis, University of Agricultural Sciences, Dharwad. 2006.

[8] D. Singh and V. Nepalia. Influence of integrated nutrient management on QPM productivity \& soil of south rajasthan. Indian Journal of Agricultural Sciences. 79(12), pp. 1020-22. 2009.

\section{Volume 4 Issue 12, December 2015}




\section{International Journal of Science and Research (IJSR) \\ ISSN (Online): 2319-7064}

Index Copernicus Value (2013): 6.14 | Impact Factor (2014): 5.611

\section{Author Profile}

Nandita Jena received the B.Sc. (Agriculture) degree from Orissa University of Agriculture and Tecnology in 2011 and M.S. (agronomy) degree from Archarya N G Ranga Agricultural Univercity in 2013. Now myself Assistant Agriculture officer through OPSC in ODISHA, India 